\title{
Supportive Mobility Across the Lifespan in Cerebral Palsy: A Modified Delphi Study to Establish Stakeholder Research Priorities
}

\author{
Heather A. Feldner, PT, PhD, PCS${ }^{1}$; Deborah Gaebler-Spira, MD $^{2}$; Varun Awasthi, BS ${ }^{3}$; Kristie Bjornson, PT, \\ $\mathrm{PhD}, \mathrm{MS}^{3}$ \\ 1. Department of Rehabilitation Medicine, University of Washington, Seattle, WA, USA \\ 2. Shirley Ryan Ability Lab, Chicago, IL, USA \\ 3. Seattle Children's Research Institute, Seattle, WA, USA
}

Corresponding Author:

Heather Feldner, PT, PhD, PCS. Assistant Professor | Division of Physical Therapy. Department of Rehabilitation Medicine, University of Washington. 1959 NE Pacific St BB 828A, Box 356490, Seattle, WA 98195. Ph: 206.543.3721 EMAIL: hfeldner@uw.edu

ORCiD: https://orcid.org/0000-0002-3659-730X

\section{Abstract}

Aim: The overarching aim of this research was to 1) Understand the mobility experiences, supported mobility device (SMD) use, and desired participation outcomes of people with cerebral palsy (CP) across the lifespan; and 2) Describe how perspectives of rehabilitation care and professional resources may influence mobility decision-making processes and outcomes. The aim of this study was to co-develop research priorities and identify meaningful research questions with a diverse group of stakeholders representing the $\mathrm{CP}$ community for implementation in subsequent research activities.

Methods: A modified, three-round Delphi consensus study was conducted with a stakeholder advisory panel consisting of three adults with $\mathrm{CP}$, two parents of children with $\mathrm{CP}$, and four SMD providers.

Results: The advisory panel identified 13 unique topical categories focused on SMD selection and use, stratified by age group and stakeholder role. Questions or statements within each category were ranked, and top consensus and concordance statements were retained, reviewed, and refined for use in a co-developed focus group guide.

Interpretation: A modified Delphi process was a useful tool for stakeholders in co-developing research priorities related to SMD use across the lifespan. Drawing on the lived expertise of stakeholders is important in facilitating improved research translation in the CP community.

Abstract Word Count: 200

NOTE: This preprint reports new research that has not been certified by peer review and should not be used to guide clinical practice. 1 
medRxiv preprint doi: https://doi.org/10.1101/2022.01.26.22269919; this version posted January 28, 2022. The copyright holder for this preprint

(which was not certified by peer review) is the author/funder, who has granted medRxiv a license to display the preprint in perpetuity.

All rights reserved. No reuse allowed without permission.

Short Title: Supportive Mobility in CP- Delphi

What this Paper Adds:

- Nine stakeholders from the CP community participated as Stakeholder Advisory Panelists and co-developers of research tools

- Stakeholders identified 175 unique responses across 12 SMD related categories

- Stakeholders prioritized 38 mobility technology research priorities during consensus-building

- Results from consensus-building will be directly implemented into a qualitative focus group protocol

List of Abbreviations:

SMD- Supportive Mobility Device

CP- Cerebral Palsy

Word Count: 2924

Cerebral Palsy (CP) is the most common childhood onset motor disability, and in the US today, nearly 800,000 people are living with $\mathrm{CP} .{ }^{1}$ While each individual living with $\mathrm{CP}$ is unique, key rehabilitation outcomes across the lifespan focus on acquisition and maintenance of mobility, whether through walking independently or through the use of supportive mobility devices (SMD) such as walkers, wheelchairs, or crutches. ${ }^{2,3}$ SMD is important for people with CP at any age but especially as motor ability changes over time. ${ }^{4}$ Many factors such as pain, body mass changes, and fatigue impact can impact mobility and walking ability across the lifespan, and over half of children with $\mathrm{CP}$ who are initially ambulatory experience regression in walking 
medRxiv preprint doi: https://doi.org/10.1101/2022.01.26.22269919; this version posted January 28, 2022. The copyright holder for this preprint (which was not certified by peer review) is the author/funder, who has granted medRxiv a license to display the preprint in perpetuity.

All rights reserved. No reuse allowed without permission.

ability by adulthood. ${ }^{5,6}$ From orthotics to complex powered mobility devices, SMD has been shown to improve function, activity, and participation. ${ }^{4,7-9}$ However, issues of social stigma, device design/size, cost, and lack of accessibility in the built environment remain, presenting significant barriers to individuals with CP who use SMD.,.$^{80-12}$

Existing literature describes these access barriers, along with mobility trends over time, biomechanical aspects of SMD use, perceptions of users and caregivers regarding their SMD, and decision-making guidelines for consideration of certain types of mobility technology, such as features of walkers or gait trainers, or introducing powered mobility when children may not walk, lose the ability to walk efficiently, or be significantly delayed in walking. ${ }^{13,14}$ In a study that examined perceived areas of importance for therapeutic intervention, youth with CP expressed that SMD was a priority, even when caregivers and healthcare providers expressed different priorities. ${ }^{15}$ Research also offers a snapshot of the realities of SMD provision in various settings, reporting that many clinicians lack training altogether, or lack confidence in their training and ability to evaluate, recommend, and adjust SMD for their clients. ${ }^{16,17}$ Despite this concerning gap, the literature underscores the importance of appropriate SMD, matched with appropriate and accessible environments, in maximizing mobility and participation outcomes. ${ }^{7-9}$

For children and adults with CP, SMD is a ubiquitous part of the lived experience, and thus an area of priority for further development and process improvement. However, little of this work has been co-developed by stakeholders from within the CP community or has involved shared-decision making recommendations specifically develop to support the procurement and use of SMD. Two examples from the current literature are notable exceptions. First, inclusion of people with CP specifically in the process of developing a focused 
research agenda was documented in Australia employing a virtual Delphi process. ${ }^{18}$

Additionally, in 2017 a group of nearly 50 stakeholders including individuals with CP, caregivers of children with $\mathrm{CP}$, and clinicians convened at Research $\mathrm{CP}$, a grant-funded conference to address the future of patient-centered $\mathrm{CP}$ research. ${ }^{19}$ The experiences and priorities that were shared specifically pointed to a gap in understanding and engaging in shared decision-making about SMD needs across the lifespan to minimize pain and fatigue and maximize activity, participation, and health in people with $\mathrm{CP}$ across all ages and functional levels. ${ }^{19}$ It is this work that has catalyzed the current study.

In recognizing stakeholder groups as experts in their field or in their lived experience, the Delphi method can be a useful research tool to employ. The Delphi method is widely used to understand and rank priorities from within a selected group of experts in a particular topic area, with an underlying assumption that group input is superior to individual input when establishing topical consensus. ${ }^{20}$ Delphi studies utilize multiple survey rounds to elicit open responses from participants, react and reply to responses of other group members, and modify or strengthen their own responses as a result of this reciprocal engagement. Although widely used across healthcare and other disciplines, the Delphi technique has only been minimally used in SMD research to date. ${ }^{18,21}$ Advantages of this technique include participant anonymity, which is intended to facilitate more open dialogue and support multiple opinions as consensus is sought, as well as the ability for the researcher to direct a controlled dialogue and feedback process toward an intended outcome. ${ }^{20}$ Anonymity between participants may be especially relevant in a mixed group of stakeholders, since power dynamics in healthcare and 
medRxiv preprint doi: https://doi.org/10.1101/2022.01.26.22269919; this version posted January 28, 2022. The copyright holder for this preprint (which was not certified by peer review) is the author/funder, who has granted medRxiv a license to display the preprint in perpetuity.

All rights reserved. No reuse allowed without permission.

rehabilitation practice have historically favored healthcare professionals over people with lived experience of a health condition. ${ }^{22}$

This study represents the first stage of a multi-phase, mixed-methods research program that aimed to investigate the processes and outcomes of SMD procurement and use across the lifespan in adults and children with CP. Our overarching objectives were to 1) Understand the mobility experiences, supported mobility device (SMD) use, and desired participation outcomes of children, youth, and adults with CP; and 2) Describe how perspectives of rehabilitation care providers (therapists, physicians, durable medical equipment vendors) and professional resources (time, knowledge, etc.) may influence mobility decision-making processes and outcomes in people with $\mathrm{CP}$ and their caregivers. This paper describes the first study stage, a modified Delphi consensus study employed with a stakeholder advisory panel representing the $\mathrm{CP}$ community to leverage shared expertise in the co-development of study priorities and focused topical questions to be implemented in the subsequent phases of the research protocol.

\section{Method}

This study was conducted with institutional approval from the [institution removed for review] Institutional Review Board (\#1490). Prior to participating in study activities, participants provided written consent for all research procedures. The study was carried out by a research team consisting of a rehabilitation physician and two pediatric physical therapists, all with extensive professional experience in working with SMD and partnering with individuals with $\mathrm{CP}$ of all ages and functional levels. 


\section{Participants}

Nine participants were recruited from within and around the CP community for a stakeholder advisory board. Purposive sampling was conducted to ensure representation from three stakeholder groups: 1) Individuals with $\mathrm{CP}$; 2) Caregivers of individuals with $\mathrm{CP}$; and 3) Healthcare professionals with expertise in SMD actively serving clients with CP. The advisory board consisted of three adults with $\mathrm{CP}$, two parents of children with $\mathrm{CP}$, and four SMD providers, who represented fields of Occupational and Physical Therapy and SMD manufacturing. Two of the adults with $\mathrm{CP}$ also had careers as physicians, thus offering multiple lived perspectives. Eight of the panelists were white, one was Asian, and one of the parents was the adoptive mother of an African American child. Panelists represented geographic regions across the US, including the Pacific Northwest, Midwest, South, and East. Each panelist was paid a $\$ 500$ honorarium for between $12-15$ hours of their time across a year-long period. In addition to completing the Delphi consensus process, panelists assisted in data analysis in subsequent study stages.

Study Procedures

A modified Delphi consensus technique was used to develop prioritized and meaningful content for use within subsequent research procedures, specifically topic content and questions for a qualitative focus group guide. Participants engaged in three rounds of online surveys, consistent with recommendations in previous literature. ${ }^{23}$ A schematic of the full Delphi process is included in Figure 1.

[insert Figure 1 about here]

Delphi Round One: Open Ended Questionnaire 
medRxiv preprint doi: https://doi.org/10.1101/2022.01.26.22269919; this version posted January 28, 2022. The copyright holder for this preprint (which was not certified by peer review) is the author/funder, who has granted medRxiv a license to display the preprint in perpetuity.

All rights reserved. No reuse allowed without permission.

A first round electronic survey presented a series of open-ended questions to gather responses regarding the most important considerations for SMD selection and use across the lifespan for people with CP. Open-ended questions were stratified into categories that considered age, functional level, and stakeholder role. A full listing of Round One categories is presented in Table 1.

[Insert Table 1 about here]

Delphi Round Two: Ranking Responses

In the second round, an electronic survey provided an aggregate, anonymous summary of responses from Round One. Responses were provided in no particular order, though duplicate responses across panelists were denoted with asterisks to indicate a high-frequency response. Within each category, panelists were asked to rank-order the top five most important topic statements or questions they wished to see carried forward in the focus group guide. Panelists were also given an opportunity to provide free responses for each category asking what (if anything) should be added, removed, or refined from the list. See Figure 2 for an example of the Round Two survey.

\section{[Insert Figure 2 about here]}

Delphi Round Three: Rankings and Agreement

The final round electronic survey provided the panel with the ranking results tallied from Round Two. Panelists were instructed to indicate whether they agreed or disagreed with the rank ordering. If disagreement was indicated, panelists were asked to provide rationale about why they remained outside of consensus. Feedback from this final round was used to 
medRxiv preprint doi: https://doi.org/10.1101/2022.01.26.22269919; this version posted January 28, 2022. The copyright holder for this preprint (which was not certified by peer review) is the author/funder, who has granted medRxiv a license to display the preprint in perpetuity.

All rights reserved. No reuse allowed without permission.

structure focus group topics and prioritize targeted questions for the qualitative focus group guide.

Data Analysis

Content analysis of open-ended Round One results was conducted to understand stakeholder priorities across categories and consolidate like responses into statements presented in Round Two. Quantitative study results from Round Two were analyzed using descriptive statistics $(\mu, S D)$ to determine the average ranking and dispersal of statements retained in each category. Due to the small sample size, consensus for statement retention was pre-defined as $>/=50 \%$ respondent agreement prior to analysis. If between $40-50 \%$ agreement was reached, these statements were labeled as concordant, to denote agreement that did not meet the threshold for consensus. Concordant statements were retained for review by the research team, but were not presented to panelists during Round Three. All statements below $40 \%$ agreement were discarded. In Round Three, percent agreement was calculated for the retained statements and any open-ended justification of disagreement comments were analyzed qualitatively for content.

\section{Results}

Results from Round One generated 175 distinct responses across 12 categories. Each category had at least one duplicate response across the panel members, with the exception of category 11 (Priorities for clinician focus group questions). Categories with the most duplicate responses included categories 2 and 3 (Most important considerations for adolescents and young adults regarding SMD) and category 12 (Priorities for SMD design over the next decade), with six responses in each category reported by multiple panelists. Because responses in categories 2 
medRxiv preprint doi: https://doi.org/10.1101/2022.01.26.22269919; this version posted January 28, 2022. The copyright holder for this preprint (which was not certified by peer review) is the author/funder, who has granted medRxiv a license to display the preprint in perpetuity.

All rights reserved. No reuse allowed without permission.

and 3 were so similar, these were combined during subsequent Delphi rounds. Categories with the least crossover in response included category 4 (Considerations for older adults regarding $S M D$ ), category 8 (Most important for physicians and therapists to know regarding $S M D$ ), category 10 (Priorities for focus group questions with individuals with CP and families), with only one item in each category reported by multiple panelists, indicating a wider dispersal of responses.

Round Two results were mixed. Rank ordering of statements resulted in clear consensus and retention of 38 statements $(21.7 \%)$, with at least one retained statement across each of the 11 consolidated categories ( $\mu=3.45$, Range $1-6$ per category). There were 32 additional statements identified as concordant (18.2\%), with a lower mean but similar range across categories ( $\mu=2.90$, Range $1-6$ per category). Categories with the greatest number of consensus statements retained included Most important considerations for young children regarding SMD (Category 1), Most important considerations for individuals with CP in GMFCS levels 2 \& 3 (Category 5), and Most important for physicians and therapists to know about SMD (Category 8). Categories with the most variability in ranking, and thus the fewest number of consensus statements retained, included Most important focus group questions to ask individuals with $C P$ and their families (Category 10), Most important focus group questions to ask physicians and therapists (Category 11), and Top priorities for SMD design and provision for individuals with CP over the next decade (Category 12). Notably, both Categories 10 and 12 had correspondingly high concordance frequencies, with 6 and 5 statements reaching concordance, respectively. A full listing of the consensus and concordance statements retained for each category are listed in Table 2. 
[Insert table 2 here]

Open-ended feedback from panelists highlighted additional areas of importance, including clinician continuing education related to SMD, identification of policy barriers and resources for funding, acceptability of SMD for participation in desired activities, and the desire to preserve physical status and energy with a multimodal ('And' rather than 'Or') approach to SMD.

Round three results indicated that panelists reported $89 \%$ agreement $(n=8)$ with the aggregate ranking results and retained statements. One panelist provided additional feedback for several categories, this feedback was discussed by the research team and incorporated into the subsequently developed research materials, however, the research team did not feel this feedback warranted a subsequent Delphi round since overall consensus was high and the panelist's open-ended responses stated baseline agreement but expanded the discussion, rather than representing a fundamental disagreement.

\section{Discussion}

This study, the first step in a mixed-methods, multi-phase research project, convened a stakeholder advisory panel from the CP community to understand important considerations and set priority topic areas and questions for subsequent research activities. A modified Delphi technique was used to establish consensus across 12 categories related to SMD, and to inform the subsequent conduction of the next study phase. ${ }^{20}$

Consensus ( $>/=50 \%)$ was met for 38 statements across a combined 12 SMD related categories. The data also showed stability (i.e. consistency across categories without necessarily 
medRxiv preprint doi: https://doi.org/10.1101/2022.01.26.22269919; this version posted January 28, 2022. The copyright holder for this preprint (which was not certified by peer review) is the author/funder, who has granted medRxiv a license to display the preprint in perpetuity.

All rights reserved. No reuse allowed without permission.

reaching pre-defined levels of consensus). ${ }^{24}$ This moderate rate of consensus was surprising at first but may be explained by the distribution of unique stakeholder experiences and perspectives within the panel. Because the survey responses were anonymous, however, it is impossible to determine if panelist characteristics played a role in ranking responses.

Nevertheless, this moderate rate of clear consensus is mirrored in other recent Delphi studies involving $\mathrm{CP}$ research, and did not appear to affect the high final round agreement toward the top-ranked statements. ${ }^{23}$

Many similarities across categories emerged, highlighting the salience of the consensus and concordance statements in regard to stakeholder priorities for research. For example, statements about the importance of trial equipment were ranked among the top three statements in two related categories (Most important for individuals with $C P$ and their families to know about SMD and Most important for physicians and therapists to know about SMD). This is consistent with extant literature describing barriers and facilitators to SMD use, including the presence or lack of trial equipment, by many individuals with disabilities and their caregivers. ${ }^{10,25}$ Similarly, across two age-group related categories (Most important SMD considerations for Adolescents and Young Adults), panelists noted priorities related to device aesthetics, as well as future-oriented thinking and planning for transition to college, work, or independent living, which is also consistent with literature describing the importance of transition services and education as young people with $\mathrm{CP}$ assume more responsibility for their healthcare and participation. ${ }^{26,27}$

Across multiple categories, provider knowledge and qualifications related to SMD emerged as a priority. This was salient from the perspective of empowering individuals with $\mathrm{CP}$ 
medRxiv preprint doi: https://doi.org/10.1101/2022.01.26.22269919; this version posted January 28, 2022. The copyright holder for this preprint (which was not certified by peer review) is the author/funder, who has granted medRxiv a license to display the preprint in perpetuity.

All rights reserved. No reuse allowed without permission.

to seek out knowledgeable healthcare professionals as well as providers themselves taking responsibility for their own learning about SMD as a topic not largely covered during professional training for physicians and therapists. Numerous studies report the need for additional competency related to assistive technology provision and policy. ${ }^{16,17}$ What remains unclear is whether individuals with $\mathrm{CP}$ and their families understand what to look for regarding provider credentials or experience, or whether existing clinicians understand how and where to access additional training resources in increasingly busy practice environments.

Finally, panelist rankings for all age and GMFCS group categories as well as priority focus group questions for individuals with $\mathrm{CP}$ indicated a desire to focus on activity and participationlevel domains as well as shared decision making related to SMD in future research. This also mirrors previous recommendations for the deployment of user-centered frameworks that placed corresponding emphasis on the person or user and their desired mobility goals, as well as the healthcare providers or clinical setting to ensure well-matched technology provision processes and products. ${ }^{7,8}$ Panelists felt this was a central issue to discuss with focus group participants, as it remains unknown how effective these methods of person-centered care for shared decision-making are played out in every day SMD provision.

\section{Study Limitations and Future Directions}

This study has several limitations. First, though the research team has professional experience in working with SMD and individuals with CP across the lifespan, it is important to note that no one has lived experience of $\mathrm{CP}$. For this reason, it was important to directly involve individuals with CP in our stakeholder advisory panel to ensure that the needs and priorities of 
medRxiv preprint doi: https://doi.org/10.1101/2022.01.26.22269919; this version posted January 28, 2022. The copyright holder for this preprint (which was not certified by peer review) is the author/funder, who has granted medRxiv a license to display the preprint in perpetuity.

All rights reserved. No reuse allowed without permission.

the CP community were represented by those with lived experience of SMD use. ${ }^{7,28}$

Additionally, the stakeholder advisory panel was comprised of only nine members, and though response rate was generally good, not all members took part in every Delphi round, thus limiting the generalizability of our results. However, current literature indicates that successful Delphi studies in healthcare may involve anywhere between 6-30 individuals, therefore the advisory panel group size remained in acceptable range. ${ }^{23,29,30}$ Further, all advisory panelists were from the US, so responses and priorities were limited to experiences within the US SMD provision system.

Future research should continue exploring stakeholder-led activities to develop meaningful research priorities and questions for the CP community, and include funding agencies as key stakeholders. While this grassroots involvement has occurred in small pockets, opportunities exist for broader-scale agenda development. ${ }^{19}$ Academic and clinical researchers and healthcare providers can leverage CP community networks to further successful translation of research into direct benefit for people with $\mathrm{CP}$ across the lifespan.

\section{Conclusion}

This study was the first phase of an overarching study to understand the mobility experiences, supported mobility device (SMD) use, and desired participation outcomes of children, youth, and adults with CP. Consensus was established for numerous statements related to research priorities and topic areas for SMD provision and use across the lifespan, which were subsequently employed in additional research activities. A Delphi process with 
medRxiv preprint doi: https://doi.org/10.1101/2022.01.26.22269919; this version posted January 28, 2022. The copyright holder for this preprint (which was not certified by peer review) is the author/funder, who has granted medRxiv a license to display the preprint in perpetuity.

All rights reserved. No reuse allowed without permission.

stakeholders in a given community of study appears to be a valuable method to ensure the setting of a meaningful agenda in $\mathrm{CP}$ research.

Funding: This work was supported by an AACPDM Pedal with Pete Foundation research grant.

Additional support for the lead author was provided by NIH NCATS KL2 TR002317).

Acknowledgements:

The authors would like to thank the members of the stakeholder advisory panel that contributed to making this project successful, and the Cerebral Palsy Research Network for their feedback in developing the overarching project.

\section{References}

1. Data and Statistics for Cerebral Palsy. Centers for Disease Control and Prevention. https://www.cdc.gov/ncbddd/cp/data.html. Updated December 30, 2020. Accessed November 16, 2020.

2. Bolton M, Donohoe M. Ambulatory Assistive Devices for Children and Youth with Cerebral Palsy. Cerebral Palsy. 2020:2963-2975.

3. Earde PT, Praipruk A, Rodpradit P, Seanjumla P. Facilitators and barriers to performing activities and participation in children with cerebral palsy: Caregivers' perspective. Pediatric Physical Therapy. 2018;30(1):27-32.

4. Palisano RJ, Hanna SE, Rosenbaum PL, Tieman B. Probability of walking, wheeled mobility, and assisted mobility in children and adolescents with cerebral palsy. Developmental Medicine \& Child Neurology. 2010;52(1):66-71. 
medRxiv preprint doi: https://doi.org/10.1101/2022.01.26.22269919; this version posted January 28, 2022. The copyright holder for this preprint (which was not certified by peer review) is the author/funder, who has granted medRxiv a license to display the preprint in perpetuity.

All rights reserved. No reuse allowed without permission.

5. Day SM, Wu YW, Strauss DJ, Shavelle RM, Reynolds RJ. Change in ambulatory ability of adolescents and young adults with cerebral palsy. Developmental Medicine \& Child Neurology. 2007;49(9):647-653.

6. Brunton LK, McPhee PG, Gorter JW. Self-reported factors contributing to fatigue and its management in adolescents and adults with cerebral palsy. Disability and Rehabilitation. 2019:1-7.

7. Palisano RJ, Shimmell L, Stewart D, Lawless JJ, Rosenbaum PL, Russell DJ. Mobility experiences of adolescents with cerebral palsy. Physical \& Occupational Therapy in Pediatrics. 2009;29(2):133-153.

8. Huang IC, Sugden D, Beveridge S. Assistive devices and cerebral palsy: factors influencing the use of assistive devices at home by children with cerebral palsy. Child: care, health and development. 2009;35(1):130-139.

9. Casey J, Paleg G, Livingstone R. Facilitating child participation through power mobility. British Journal of Occupational Therapy. 2013;76(3):158-160.

10. Feldner HA, Logan SW, Galloway JC. Why the time is right for a radical paradigm shift in early powered mobility: the role of powered mobility technology devices, policy and stakeholders. Disability and Rehabilitation: Assistive Technology. 2016;11(2):89-102.

11. Østensjø S, Carlberg EB, Vøllestad NK. The use and impact of assistive devices and other environmental modifications on everyday activities and care in young children with cerebral palsy. Disability and Rehabilitation. 2005;27(14):849-861.

12. Palisano RJ, Tieman BL, Walter SD, et al. Effect of environmental setting on mobility methods of children with cerebral palsy. Developmental medicine and child neurology. 2003;45(2):113-120.

13. Livingstone R, Paleg G. Practice considerations for the introduction and use of power mobility for children. Developmental Medicine \& Child Neurology. 2014;56(3):210-221.

14. Paleg G, Livingstone R. Evidence-informed clinical perspectives on selecting gait trainer features for children with cerebral palsy. International Journal of Therapy and Rehabilitation. 2016;23(9):444-454.

15. Vargus-Adams JN, Martin LK. Domains of importance for parents, medical professionals and youth with cerebral palsy considering treatment outcomes. Child: care, health and development. 2011;37(2):276-281.

16. Long TM, Perry DF. Pediatric Physical Therapists' Perceptions of Their Training in Assistive Technology. Physical Therapy. 2008;88(5):629-639.

17. Karlsson P, Johnston C, Barker K. Influences on students' assistive technology use at school: the views of classroom teachers, allied health professionals, students with cerebral palsy and their parents. Disability and Rehabilitation: Assistive Technology. 2018;13(8):763-771.

18. Mclntyre S, Novak I, Cusick A. Consensus research priorities for cerebral palsy: A delphi survey of consumers, researchers, and clinicians. . Developmental Medicine \& Child Neurology. 2010(52):270-275.

19. Gross PH, Bailes AF, Horn SD, Hurvitz EA, Kean J, Shusterman M. Setting a patient-centered research agenda for cerebral palsy: a participatory action research initiative. Developmental Medicine \& Child Neurology. 2018;60(12):1278-1284.

20. Hsu C-C, Sandford BA. The Delphi technique: making sense of consensus. Practical Assessment, Research, and Evaluation. 2007;12(1):10.

21. Jefferds AN, Pearlman JL, Wee J, Cooper RA. International Mobility Technology Research: A Delphi Study to Identify Challenges and Compensatory Strategies. Assistive Technology. 2011;23(4):232-242.

22. O'Shea A, Boaz AL, Chambers M. A Hierarchy of Power: The Place of Patient and Public Involvement in Healthcare Service Development. Frontiers in Sociology. 2019;4. 
medRxiv preprint doi: https://doi.org/10.1101/2022.01.26.22269919; this version posted January 28, 2022. The copyright holder for this preprint

(which was not certified by peer review) is the author/funder, who has granted medRxiv a license to display the preprint in perpetuity.

All rights reserved. No reuse allowed without permission.

23. Dewar R, Claus AP, Tucker K, Johnston LM. Perspectives on postural control dysfunction to inform future research: a Delphi study for children with cerebral palsy. Archives of physical medicine and rehabilitation. 2017;98(3):463-479.

24. Cuthbertson BH, Goddard SL, Lorencatto F, et al. Barriers and Facilitators to Early Rehabilitation in the ICU: A Theory Driven Delphi Study. Critical Care Medicine. 2020;48(12):e1171-e1178.

25. Rosen L, Plummer T, Sabet A, Lange ML, Livingstone R. RESNA position on the application of power mobility devices for pediatric users. Assistive Technology. 2018:1-9.

26. Freeman M, Stewart D, Cunningham C, Gorter J. "If I had been given that information back then": An interpretive description exploring the information needs of adults with cerebral palsy looking back on their transition to adulthood. Child: care, health and development. 2018;44(5):689-696.

27. Liljenquist $\mathrm{K}, \mathrm{O}^{\prime} \mathrm{Neil} \mathrm{ME}$, Bjornson KF. Utilization of physical therapy services during transition for young people with cerebral palsy: a call for improved care into adulthood. Physical therapy. 2018;98(9):796-803.

28. Huang I-C, Sugden D, Beveridge $S$. Children's perceptions of their use of assistive devices in home and school settings. Disability and Rehabilitation: Assistive Technology. 2009;4(2):95-105.

29. De Villiers MR, De Villiers PJ, Kent AP. The Delphi technique in health sciences education research. Medical teacher. 2005;27(7):639-643.

30. Danial-Saad A, Kuflik T, Weiss PL, Schreuer N. Building an ontology for assistive technology using the Delphi method. Disability and Rehabilitation: Assistive Technology. 2013;8(4):275-286.

\section{Tables and Figure Captions}

Table 1.Delphi Round 1 Open Ended Question Categories

Category Question

1 Most Important Considerations for young children regarding SMD selection and use

2* Most important considerations for adolescents regarding SMD selection and use

3* Most important considerations for young adults regarding SMD selection and use

4 Most important considerations for older adults regarding SMD selection and use 
medRxiv preprint doi: https://doi.org/10.1101/2022.01.26.22269919; this version posted January 28, 2022. The copyright holder for this preprint

(which was not certified by peer review) is the author/funder, who has granted medRxiv a license to display the preprint in perpetuity.

All rights reserved. No reuse allowed without permission.

5 Most important considerations for individuals with CP in GMFCS levels 2 \& 3

6 Most important considerations for individuals with CP in GMFCS levels 4 \& 5

7 Most important for suppliers and manufacturers of SMD to know

8 Most important for physicians and therapists to know about SMD

9 Most important for individuals with CP and their families to know about their options for SMD

10 Most important focus group questions to ask individuals with $\mathrm{CP}$ and their families

11 Most important focus group questions to ask physicians and therapists

12 Top priorities for SMD design and provision for individuals with CP over the next decade

*Categories 2 and 3 were combined following Round 1 due to the similarities in panelist responses. 
Category Topic

1 Most Important Considerations for young children regarding SMD selection and use

Most important considerations for adolescents regarding SMD selection and use

Most important considerations for ( selection and use Most important considerations for older adults regarding SMD selection and use

Omportant considerations for individuals with CP in GMFCS levels 2 \& 3
Retained Statements (ranking $\mu, S D$ )

1. 'Mobility and Independence' $(1.75,0.96)$

2. 'Ease of Use/Functionality' $(2.86,1.35)$

3. 'How the device will accommodate for growth' (3, 1.90)

4. 'How SMD will support play/misbehaving and integration of peers' $(3.25,0.96)$

1. 'Independence' $(1.5,0.55)$

2. 'Aesthetics, something cool looking' $(2,1.41)$

3. 'Future thinking/planning for transition to college/work/independent living' $(3.75,0.96)$

1. 'Expense of the device/funding eligibility' (2.2, 1.64)

2. 'Need for increased comfort/support due to pain with aging' $(2.5,0.58)$

3. 'How SMD will be used i.e. part vs. full time, one vs many mobility tools' $(3,1.15)$

4. 'Choicemaking/Decision-making power regarding $S M D^{\prime}(3,1.41)$

1. 'Need for a Selection framework geared toward how using a SMD will allow efficiency/energy conservation to improve participation' (1.83, 1.17)

2. 'Not an 'or' decision but an 'and' decision together with upright mobility $(2.6,0.55)$
Concordant Statements $* *$

1. 'How SMD will accommodate for changing function over time'

2. 'How SMD will support continued development of gross motor skills'

3. 'Portability'

1. 'SMD that will let them get around in their ever-expanding worlds'

2. 'Device-Environment Match'

1. 'Maintenance Requirements'

1. 'Individual's preferences for mobility' 


\section{individuals with CP in GMFCS \\ levels 4 \& 5}

\section{Most important for suppliers and} manufacturers of SMD to know
3. 'How style of SMD impacts participation and energy level' $(4,2)$

4. 'Access needs (Cognitive abilities, visual/auditory acuity, spasticity, contractures)' $(4.25,0.50)$

5. 'Portability' $(4.5,0.58)$

1. 'Having therapists/suppliers with knowledge of more complex functional issues and equipment needs' $(2.83,0.98)$

2. Availability of trial equipment especially with alternative access drive methods- eval process will take longer but necessary for success' $(3,1)$

3. 'What brings the individual joy' $(3,1.63)$

4. 'Customizability-people are not symmetrical' $(3.75,1.89)$

1. 'All people with CP are different' $(1.2,0.45)$

2. 'Need for increased communication between manufacturers and funders for affordability and design' $(2.5,1)$

3. 'Options/Choices for customization' $(3.75,1.26)$

1. 'Real-life practical benefit must be discussed/communicated' $(2,0.82)$

2. 'It is easy for bias/judgement of clinician to influence how client/caregiver views $\operatorname{SMD}(2,2)$

3. 'Trial equipment is a must' $(2.75,1.50)$

4. 'Consider entire support system, not just the individual' $(3,1.83)$

5. 'Selection of SMD must 'fit' into life and environments' $(3.5,1.29)$
1. 'Ability of the SMD to support/ accommodate add-on augmentative communication systems and mount where it is accessible but not in way of participation'

2. What the individual can do independently'

3. 'Function'

1. 'Expense'

2. 'Need for unbiased education for SMD users about choice'

3. 'Provision and education must focus on unique needs of individual/family'

4. 'SMD should be lightweight to aid in lifting/transport'

1. 'Bottom line is efficiency and participation as defined by the SMD user'

2. 'Expense'

3. 'There is no cookie cutter solution, trial and error will happen' 
9 Most important for individuals with CP and their families to know about their options for SMD

Most important focus group questions to ask individuals with $\mathrm{CP}$ and their families

Most important focus group questions to ask physicians and therapists

Top priorities for SMD design and provision for individuals with $\mathrm{CP}$ over the next decade
1. Information about funding, what it does and does not cover, including options for private pay/alternative funding' $(1.75,1.5)$

2. 'SMD is best explored through an eval that includes a therapist (providing guidance about fit and use of SMD) and supplier (providing guidance about equipment features and adjustability) together' $(2,0.82)$

3. 'Trial equipment is essential to determine what will work best' $(3,1.22)$

4. 'Resources for qualified therapists and vendors' $(4,0.82)$

1. 'Who decided what type of SMD you needed and how much say did you have?' $(3.33,1.37)$

1. 'What are your roadblocks when it comes to recommending wheeled mobility?' $(3.25,1.26)$

2. 'How do you participate in evaluations and fittings/trainings for SMD together with suppliers?' $(3.8,1.64)$

1. 'Mindset of supporting mobility across the lifespan' $(2.5,1)$

2. 'Portability' $(2.75,1.5)$
1. 'Walking is not always a measure of success'

2. 'SMD should be recommended based on client needs, not based on what may or may not be covered by insurance'

1. 'What are your mobility goals'

2. 'How have you accessed the SMD you need'

3. 'Did you get to try the SMD before it was selected'

4. 'Describe your previous experiences with $S M D$. What have you had, what did you like/not like about it'

5. 'What resources do you have/use for identifying qualified vendors/therapists'

1. 'How do you evaluate SMD utility?

2. 'Describe your thoughts about individuals having multiple SMD solutions depending on activities or environments'

1. 'Affordability'

2. 'Resources for funding'

3. 'Streamlining the insurance approval process' 
4. 'Educating insurance providers about longterm cost savings when appropriate SMD is approved'

5. Increasing the number of qualified SMD providers'

6. 'Function'

*Categories 2 and 3 were combined for Rounds 2 and 3 due to similarities in responses

**Mean and standard deviation not reported for Concordant Statements since ranking responses were below threshold for consensus.

Statements that reached concordance were reviewed by the research team as part of data analysis but not included in Delphi Round 3.

\section{Figure Captions}

Figure 1: This modified Delphi study employed three rounds of consensus building to determine topical priorities and questions for a focus group guide to be used in a subsequent qualitative study. An open-ended first round resulted in statements from panelists across 12 categories. The second round involved rank ordering the top five statements in 11 categories in order of importance (two categories were combined in Round 2 due to the similarity of responses in Round 1), and the third round presented the rank-order results and assessed agreement between stakeholder panelists.

Figure 2: An example of the Round 2 Delphi rank ordering exercise for Category 1 from Round 1. Panelists were asked to rank order the top five most important statements within each category and leave the remaining statements in each category blank. 
medRxiv preprint doi: https://doi.org/10.1101/2022.01.26.22269919; this version posted January 28, 2022. The copyright holder for this preprint (which was not certified by peer review) is the author/funder, who has granted medRxiv a license to display the preprint in perpetuity.

All rights reserved. No reuse allowed without permission.

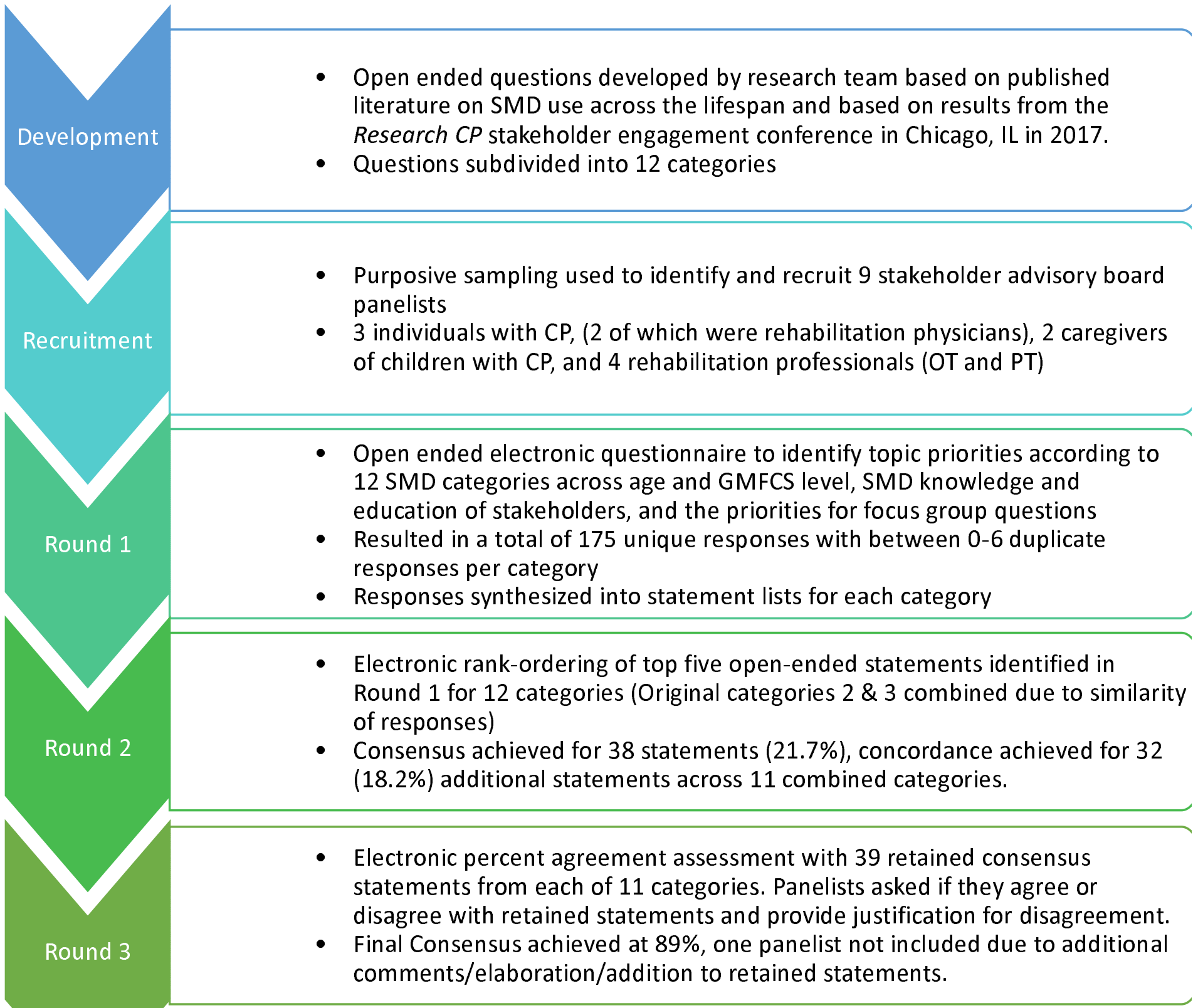

Figure 1. Delphi Consensus Building Process

Figure Caption: This modified Delphi study employed three rounds of consensus building to determine topical priorities and questions for a focus group guide to be used in a subsequent qualitative study. An open-ended first round resulted in statements from panelists across 12 categories. The second round involved rank ordering the top five statements in 11 categories in order of importance (two categories were combined in Round 2 due to the similarity of responses in Round 1), and the third round presented the rank-order results and assessed agreement between stakeholder panelists. 
medRxiv preprint doi: https://doi.org/10.1101/2022.01.26.22269919; this version posted January 28, 2022. The copyright holder for this preprint (which was not certified by peer review) is the author/funder, who has granted medRxiv a license to display the preprint in perpetuity.

All rights reserved. No reuse allowed without permission.
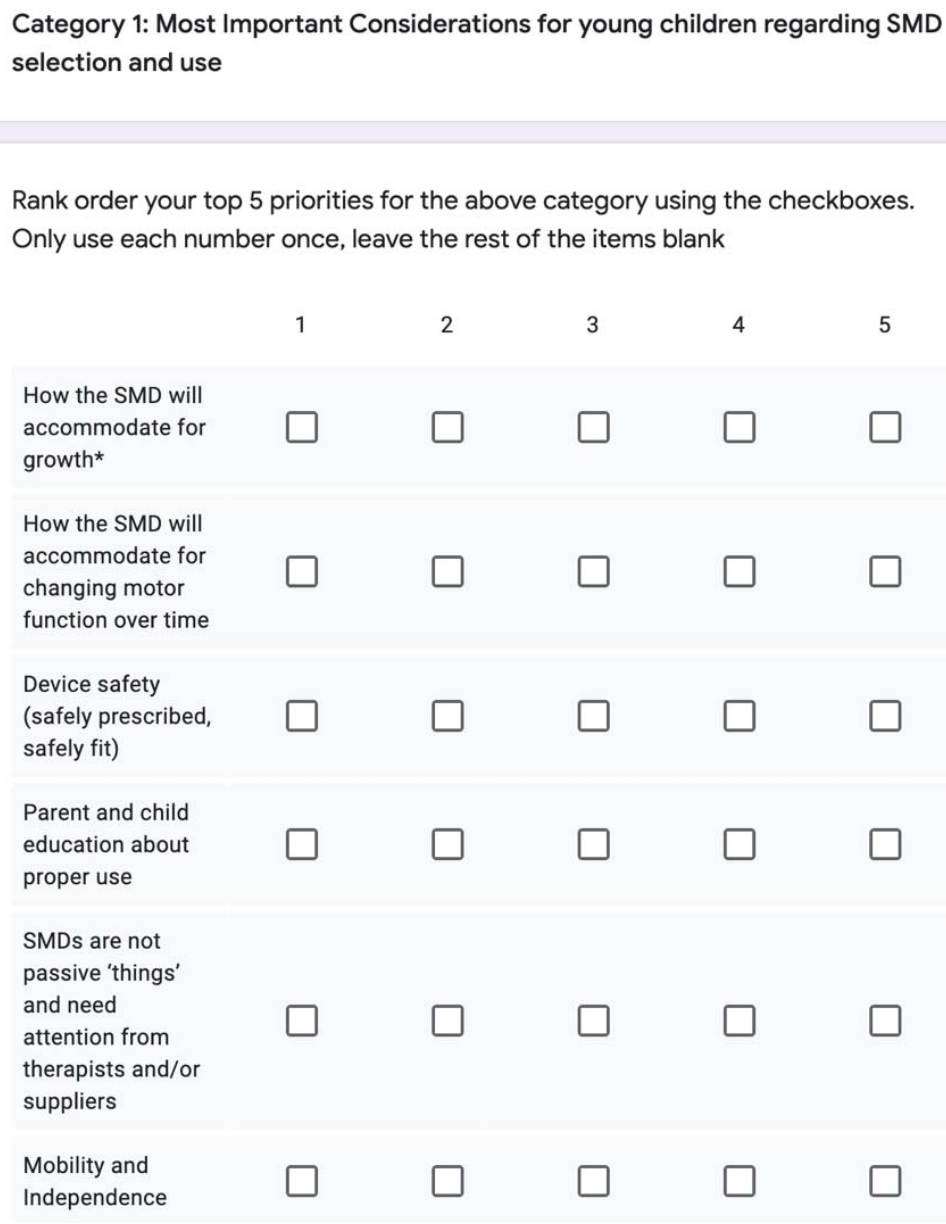

Figure 1. Delphi Round 2 Rank Ordering Sample

Figure 2 Caption: An example of the Round 2 Delphi rank ordering exercise for Category 1 from Round 1. Panelists were asked to rank order the top five most important statements within each category and leave the remaining statements in each category blank. 